\author{
Демчук Володимир,
}

E-mail: ready_ds@ukr.net, ORCID iD 0000-0002-3645-1124

\title{
СТАН НОРМАТИВНО-ПРАВОВОГО РЕГУЛЮВАННЯ МІЖВІДОМЧОЇ ВЗАЕМОДІЇ ОРГАНІВ ДЕРЖАВНОЇ ВЛАДИ ТА МІСЦЕВОГО САМОВРЯДУВАННЯ
}

\section{https://doi.org/10.32689/2618-0065-2021-1(7)-98-119}

Анотація. Аналіз небезпек і загроз техногенного та природного характеру, виникнення надзвичайних ситуацій свідчить, що за останні 10 років тенденції до їх збільшення або зменшення не спостерігається, але варто відмітити, що рівень ризиків виникнення НС природного і техногенного характеру та ризиків збитків від них залишаються практично незмінними та досить високими для більшості регіонів України. А наслідки надзвичайної ситуації, що пов'язана 3 розповсюдженням корона вірусу COVID-19, непередбачувані i вимагають науково-методологічного обгрунтування методик іx прогнозування та розрахунку. Ситуація в світі 3 розповсюдженням корона вірусу ще раз довела, що небезпеки виникнення НС $є$ фактором, що визначає якість життя у регіонах будь-якої країни. Це зумовлює нагальну потребу докладного перегляду організаційноуправлінських підходів щодо їх моделювання та мінімізації. Традиційні підходи до управління подоланням комплексних наслідків НС, як доводить досвід їх застосування, часто призводять до незадовільних результатів. Також серйозною проблемою організації ефективного управління за умов $\mathrm{HC}$, як показала практика реагування на $\mathrm{HC}$, що пов'язана 3 розповсюдженням корона вірусу, $є$ реальне ускладнення або відсутність координації дій офіційних урядових, відомчих і неурядових органів управління. Виявлено, що законодавством України визначено основні положення щодо реалізації політики держави у сфері цивільного захисту в цілому, та означено основи побудови єдиної державної системи цивільного захисту. Доведено, що у вказаних законодавчих актах вказано структуру, функції та завдання системи управління єдиної державної системи цивільного захисту. Визначено, що проблема побудови системи управління ЄДСЦЗ на територіальному та функціональному рівні, a також удосконалення послідовності та змісту роботи органів управління у надзвичайних ситуаціях та організації взаємодії, як елементу процесу управління, потребує додаткового дослідження та наукового обгрунтування. Ключові слова: нормативно-правове регулювання, міжвідомча взаємодія, цивільний захист, надзвичайна ситуація, COVID-19. 


\section{Науковий вісник : Державне управління №1 (7) 2021}

Постановка проблеми. На сьогоднішній день відбувається збільшення кількості природних та техногенних надзвичайних ситуацій, наслідки яких змушують розглядати їх загрозу як безпеку суспільству, довкіллю, так і розвитку економіки країни. Надзвичайні ситуації (НС), які відбулись у XXI столітті, особливо, що пов'язана 3 пандемією, показали, що управління цивільним захистом не $\epsilon$ ефективним i не тільки в Україні.

Аналіз виникнення НС на території України протягом останніх 10 років свідчить про те, що в середньому, в державі щороку виникає близько 150 надзвичайних ситуацій, a їх кількість, починаючи з 2013 року практично залишається незмінною (табл. 1). Зрозуміло, що НС, що пов'язана з розповсюдженням корона вірусу, за своїми масштабами i наслідками, які ще треба усвідомити, перевершила всі їх взяті разом.

\section{Таблицяя 1 - Динаміка показників НС за характером і масштабом}

(2010 - 2019$)$ років*

\begin{tabular}{|l|c|c|c|c|c|c|c|c|c|c|c|}
\hline Показник & $\begin{array}{c}\mathbf{2 0 1 0} \\
\text { piк }\end{array}$ & $\begin{array}{c}\mathbf{2 0 1 1} \\
\text { рiк }\end{array}$ & $\begin{array}{c}\mathbf{2 0 1 2} \\
\mathbf{p i \kappa}\end{array}$ & $\begin{array}{c}\mathbf{2 0 1 3} \\
\mathbf{p i \kappa}\end{array}$ & $\begin{array}{c}\mathbf{2 0 1 4} \\
\mathbf{p i \kappa}\end{array}$ & $\begin{array}{c}\mathbf{2 0 1 5} \\
\mathbf{p i \kappa}\end{array}$ & $\begin{array}{c}\mathbf{2 0 1 6} \\
\mathbf{p i \kappa}\end{array}$ & $\begin{array}{c}\mathbf{2 0 1 7} \\
\mathbf{p i \kappa}\end{array}$ & $\begin{array}{c}\mathbf{2 0 1 8} \\
\mathbf{p i \kappa}\end{array}$ & $\begin{array}{c}\mathbf{2 0 1 9} \\
\text { рiк }\end{array}$ & $\begin{array}{c}\text { Всього } \\
\text { НС за } \\
\mathbf{1 0} \\
\text { років }\end{array}$ \\
\hline Всього НС & 254 & 221 & 212 & 144 & 143 & 148 & 149 & 166 & 128 & 146 & 1711 \\
\hline $\begin{array}{l}\text { за характером } \\
\text { природні }\end{array}$ & 135 & 134 & 120 & 76 & 74 & 63 & 56 & 50 & 48 & 60 & 816 \\
\hline техногенні & 108 & 77 & 74 & 56 & 59 & 77 & 89 & 107 & 77 & 81 & 805 \\
\hline соціальні & 11 & 10 & 18 & 12 & 10 & 8 & 4 & 9 & 3 & 5 & 90 \\
\hline $\begin{array}{l}\text { за рівнем } \\
\text { державний }\end{array}$ & 5 & 4 & 1 & 1 & 5 & 2 & 1 & 2 & 2 & 2 & 25 \\
\hline регіональний & 16 & 3 & 13 & 12 & 9 & 9 & 9 & 8 & 6 & 7 & 92 \\
\hline місцевий & 107 & 89 & 83 & 58 & 59 & 62 & 64 & 70 & 64 & 63 & 719 \\
\hline об'єктовий & 126 & 125 & 115 & 73 & 70 & 75 & 75 & 86 & 56 & 74 & 875 \\
\hline загинуло, осіб & 361 & 355 & 301 & 253 & 287 & 242 & 183 & 172 & 168 & 199 & 2521 \\
\hline $\begin{array}{l}\text { постраждало, } \\
\text { осіб }\end{array}$ & 753 & 985 & 861 & 854 & 680 & 962 & 1805 & 892 & 839 & 1492 & 10123 \\
\hline $\begin{array}{l}\text { матеріальні } \\
\text { збитки, млн.грн. }\end{array}$ & 984,7 & 102,8 & 249,8 & 396,3 & 198,9 & 532,7 & 265,3 & 896,8 & 496,9 & 685,3 & 4809,5 \\
\hline
\end{tabular}

Незважаючи на таку сталу тенденцію, ризик виникнення в Україні НС техногенного характеру $\epsilon$ досить високим, що насамперед пов'язано 3 високим рівнем техногенного 
навантаження на регіони, наявністю комплексу гірничодобувних, хімічних, енергетичних об'єктів, значною кількістю промисловоміських агломерацій i високою щільністю населення у промислово-розвинутих регіонах держави.

Крім цього, загрозу виникнення НС природного характеру несуть небезпечні метеорологічні явища та складні погодні умови (снігопади, ожеледь, хуртовини, зливи, градобій, заморозки, посухи, спека, урагани, шквали, смерчі), гідрологічні явища (повені, селі, паводки, підтоплення), геологічні явища (небезпечні екзогенні геологічні процеси - зсуви, просідання та карст), епідемії та пандемії.

За період моніторингу НС, що виникли в Україні за період 3 2011 по 2020 роки, сталося 1573 НС. За класифікаційними ознаками НС розподілилися наступним чином: техногенного характеру - 728 НС, природного характеру - 761 НС, соціального характеру - 84. Внаслідок НС загинуло 2331 особа та постраждало 9675 осіб, а прямі матеріальні збитки становлять більше 14682,93 млн. грн.

Динаміка виникнення НС та їх наслідки показано на рис.1

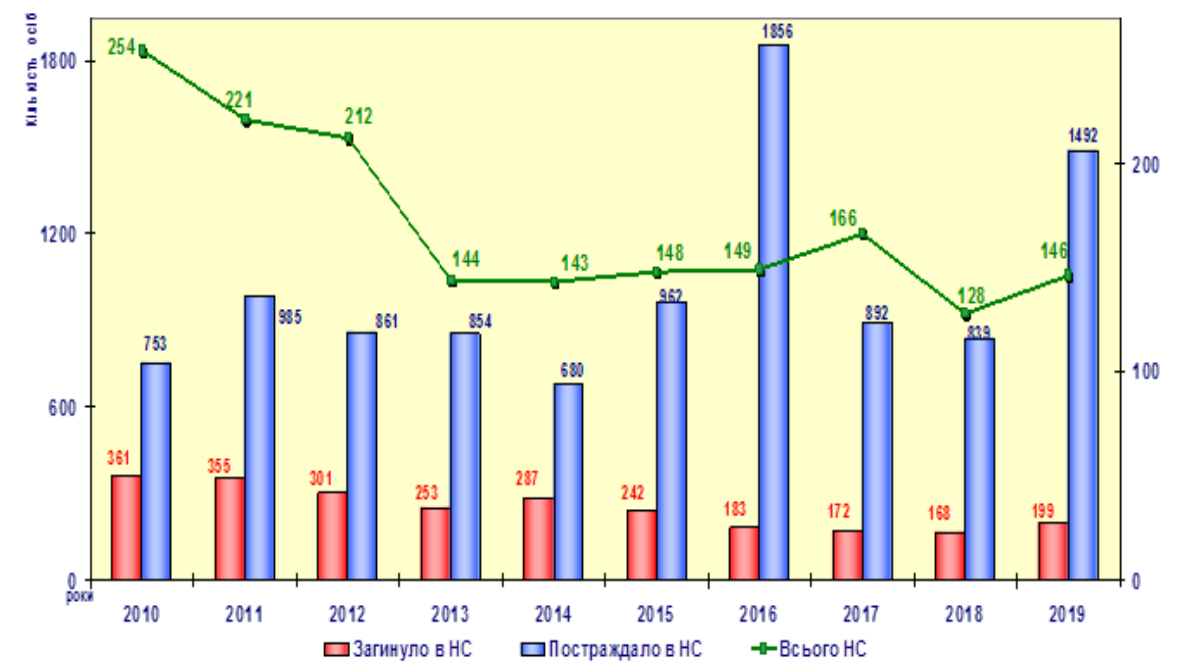

Рисунок 1 - Динаміка виникнення НС та їх наслідків* 


\section{Науковий вісник : Державне управління №1 (7) 2021}

Отже, аналіз небезпек і загроз техногенного та природного характеру, виникнення надзвичайних ситуацій свідчить, що за останні 10 років тенденції до їх збільшення або зменшення не спостерігається, але варто відмітити, що рівень ризиків виникнення НС природного і техногенного характеру та ризиків збитків від них залишаються практично незмінними та досить високими для більшості регіонів України.

Таким чином можна констатувати, що ризики виникнення надзвичайних ситуацій залишаються достатньо високими, а як показує практика, при реагуванні на них існують прогалини в організації управління реагуванням та ліквідацією наслідків НС. Наразі, недосконалою залишається організація взаємодії між різними рівнями органів управління, органів влади і місцевого самоврядування, сили яких задіються до реагування [2]. Це зумовлює потребу вдосконалення організаційно-управлінських процесів в умовах НС та пошуку шляхів удосконалення методів $\mathrm{i}$ форм організації міжвідомчої взаємодії на державному рівні, підвищення ефективності міжвідомчої координації та взаємодії органів управління та сил цивільного захисту із збройними силами, правоохоронними формуваннями та центральними органами виконавчої влади, впровадження інноваційнокомунікаційних форм взаємодії рятувальних підрозділів і служб 3 інститутами громадянського суспільства.

Аналіз попередніх досліджень. Науково-методологічною базою досліджень у сфері публічного управління та адміністрування, наразі й нашого, є напрацювання В. Бакуменко. Автор науково-теоретично обгрунтував засади формування державно-управлінських рішень і визначив шляхи застосування отриманих наукових результатів у практиці державного управління в Україні [3, 4].

Дослідженню проблемних питань державного управління загалом, та державного управління у сфері цивільного захисту зокрема, присвячено низку наукових праць [5].

Також теоретико-методологічним підгрунтям нашого дослідження $є$ напрацювання науковців Інституту державного управління та наукових досліджень 3 цивільного захисту. 


\section{Науковий вісник : Державне управління №1 (7) 2021}

Зокрема, положення про особливості державного управління у сфері цивільного захисту. Професора кафедри державного управління у сфері цивільного захисту П. Волянський, О. Свсюков, А. Терент'єва зазначають, що державне управління у цій сфері має певні особливості, що пов'язані із «...зменшенням часу на розроблення, прийняття та реалізацію управлінських рішень, зростання невизначеності та ризику, необхідність залучення 3 резервів додаткових ресурсів, наявність різних режимів функціонування системи державного управління в умовах НС» [6, c. 47]. Урахування цих особливостей надасть можливість зменшити вірогідність прийняття неадекватних управлінських рішень, сприятиме економії ресурсів та часу на ліквідацію наслідків НС i зменшенню збитків

В. Костенко відмічає, що характер і масштаб природнотехногенних та військових загроз національній безпеці України спонукає до вирішення на державному рівні завдання запобігання надзвичайним ситуаціям, реагування на них, захисту населення, об'єктів економіки, національного надбання від надзвичайних ситуацій. Чітке розуміння цього факту зумовлює вжиття з боку держави адекватних заходів, суть яких полягає у створенні цілісної системи убезпечення населення й територій від надзвичайних ситуацій природного, техногенного та військового характеру і проведення виваженої державної політики 3 цих питань. В. Костенко запропонував авторське визначення поняття „трасування державного управління в умовах надзвичайних ситуацій” - як діяльність суб'єктів управління, спрямована, на жорсткий покроковий процес розроблення керівних впливів на керовані підсистеми, 3 метою досягнення максимальної ефективності дій за певних умов відповідно до отриманого завдання 3 вищого рівня управління процесом узгодження дій системи за місцем, часом, виконавцями, ресурсами, що вказує на послідовність дій у складних ділянках трасування, контролюючи результат з векторизації ланцюга та правил трасування [7].

На основі характеризації державного управління захистом населення у надзвичайних ситуаціях В. Костенком розроблено алгоритм трасування державного управління у сфері захисту 


\section{Науковий вісник : Державне управління №1 (7) 2021}

населення в умовах надзвичайних ситуацій: 1-й етап „інтеграції” (початкова точка), який включає три кроки: 1-й згуртування в роботі чинної організаційної структури єдиної системи цивільного захисту; 2-й - згуртування спеціально уповноважених центральних органів виконавчої влади 3 питань цивільного захисту; 3-й - згуртування органів мінімізації наслідків Чорнобильської катастрофи та інших надзвичайних ситуацій; 2-й етап - “асоціації" (уперед), який включає три кроки: 1-й - зв'язок з метою здійснення угод органів управління та сил цивільного захисту, що виконують завдання цивільного захисту; 2-й - зв'язок з метою здійснення угод регіональних та місцевих органів управління; 3-й - зв'язок з метою здійснення угод структур центрального апарату ДСНС України; 3-й етап „межі тривкості” (уперед - праворуч), який включає три кроки: 1-й - „компіляції”, зсув ліворуч - руйнування системи; 2-й - „об'єктивний”, визначення межі руйнування; 3-й - ,реалізації’, зсув праворуч - запуск програми реалізації інтегрованої системи управління процесами захисту населення в надзвичайних ситуаціях на рівні наддержавних, державних структур, недержавних організацій - суб'єктів національної безпеки (кінцева точка) [7].

Особливістю системи управління цивільним захистом $є$ те, що в ній задіяні органи управління різних міністерств та відомств, органи державної влади та місцевого самоврядування. Це, з одного боку, ускладнює процес прийняття рішень, 3 іншого боку, при налагодженій співпраці, дає можливість задіяти можливості різних стейхолдерів.

П. Волянський узагальнив досвід спільної роботи аварійнорятувальних підрозділів у складі міжнародних спільних гуманітарних операцій. Координування спільних цивільновійськових дій та взаємної підтримки здійснюються через обмін інформацією, об'єднане планування та спільну оцінку ситуації яка склалась, через проведення спільних нарад, перемовин тощо. Ключовим моментом всієї координації є обмін інформацією. Автор зазначає, що пошук і порятунок людей при катастрофах $\mathrm{i}$ НС $з$ великою кількістю постраждалих (витоки нафти й особливо 


\section{Науковий вісник : Державне управління №1 (7) 2021}

небезпечних хімічних речовин, непоодинокі випадки терористичних актів) складають 80\% від всієї кількості випадків, тому ліквідація їх наслідків відбувається згідно заздалегідь розроблених принципів й алгоритмів. Решта випадків $\epsilon$ комплексними, тобто з поєднанням специфіки декількох випадків одночасно. Основним організаційним принципом взаємодії повинна бути система горизонтальних та вертикальних зв'язків рівнів реагування, що побудовані на єдиній інформаційноаналітичній системі, при чому прийняття рішень щодо класифікації та кодифікації НС та визначення рівня реагування повинно відноситься до компетенції СМОС. Другим наріжним принципом повинна бути уніфікація та стандартизація заходів медичного захисту, що дозволяє забезпечити оптимальні умови для створення резервів, підготовки кадрів медичного i допоміжного персоналу, а також ефективності функціонування спадкоємності етапів. Найбільш ефективним видом координації $є$ спільне планування та оцінка ситуації, яка склалась. Координація та взаємна підтримка має бути досягається взаємоузгодженістю дій на всіх рівнях, розпочинаючи від найвищого державного i закінчуючи локальним рівнем [8].

В. Михайлов обгрунтував теоретико-методологічні засади i розробив практичні рекомендації щодо вдосконалення взаємодії органів місцевого самоврядування з органами державної влади в процесі запобігання та ліквідації надзвичайних ситуацій. Автором обгрунтовано структурну схему міжтериторіальної взаємодії органів місцевого самоврядування 3 органами державної влади у сфері запобігання та ліквідації НC, що реалізуються за принципом субсидіарності, застосування якої забезпечує вирішення питань у цій сфері на міжтериторіальному рівні як підсистемі єдиної державної системи цивільного захисту (далі - СДСЦЗ); запропоновано упровадження аутсорсингу як організаційно-економічного інструменту взаємодії органів місцевого самоврядування з органами державної влади в процесі реалізації завдань у сфері запобігання та ліквідації $\mathrm{HC}$; розроблено модель взаємодії органів місцевого самоврядування 3 органами державної влади, що базується на нормативній, 


\section{Науковий вісник : Державне управління №1 (7) 2021}

адміністративній, фінансовій, оперативній формах взаємодії та контролі за виконанням органами місцевого самоврядування наданих державних повноважень при застосуванні організаційноправового механізму і організаційно-економічного інструменту їх взаємодії, які визначають оптимальні шляхи реалізації завдань у сфері запобігання та ліквідації НС [9].

Колективом науковців під керівництвом С. Потеряйка ініційовано та проведено науково-дослідну роботу «Дослідження методів організації взаємодії між силами цивільного захисту у надзвичайних ситуаціях» [2]. У процесі розв'язання завдань розроблено пропозиції щодо удосконалення правового, організаційного та економічного аспектів, які викладено у [10].

Науковцями виявлено проблему, сутність якої полягає у протиріччі, що криється, з одного боку у зростанні кількості та ускладненні змісту завдань, що постають перед керівником 3 ліквідації НС, а з іншого - недостатнім рівнем його знань і умінь щодо обрання найбільш раціонального методу роботи у конкретній НС. Зазначене свідчить про недостатньо досліджені дотепер науково-методичні підходи до вирішення питань визначення раціональної послідовності та змісту дій керівника, що забезпечують виконання завдань у складних умовах виникнення та розвитку НС та організації взаємодії. Крім того, виявлено, що недоліки в роботі керівників органів управління у надзвичайних ситуаціях, переважною більшістю, пов'язані із сукупністю недостатньої професійної підготовки керівників та їх якостей, що проявляються в складних умовах обстановки [6].

С. Гур'єв із співавторами [11] досліджував проблему отримання адекватної та своєчасної інформації про наслідки надзвичайної ситуації безпосередньо із зони НС для прийняття управлінських рішень. Доведено, що опрацювання управлінських рішень в процесі ліквідації наслідків НС, зокрема медикосанітарних, як найбільш важких i важливих, потребує удосконалення не тільки завдяки використання сучасних інформаційних технологій і потужного математичного апарату, а особливо аналізу вітчизняного досвіду ліквідації НС та створення оперативних планів реагування на виникнення НС на всіх рівнях 
системи державного управління, що $\epsilon$ складовими інформаційного супроводу.

Аналіз бази наукових робіт дозволяє стверджувати, що в попередніх наукових дослідженнях [5] розглядалися деякі питання наукового обгрунтування удосконалення функціонування системи цивільного захисту. У цих роботах досліджено певним чином особливості модернізації цієї системи в сучасних умовах, стан нормативно-правової бази у сфері цивільного захисту, структуру, функції та завдання, що покладені на органи влади при ліквідації наслідків НС, рівень їхньої оснащеності та кадрового забезпечення, а також використання міжнародного досвіду для підвищення ефективності діяльності системи цивільного захисту, роль і значення іiі інформаційноаналітичного забезпечення.

Однак питання організації міжвідомчої взаємодії при організації цивільного захисту в цілому, зокрема при реагуванні та ліквідації наслідків НС розкрито не у повному обсязі. А слушні пропозиції, що запропоновані колективом авторів під керівництвом С. Потеряйко [2], ще не знайшли свого місця в системі нормативно-правового регулювання міжвідомчої взаємодії органів управління в системі попередження, реагування, мінімізації та ліквідації наслідків НС. Аналіз стану якого ми і визначаємо науковим завданням.

Мета статті. Проаналізувати стан нормативно-правового регулювання міжвідомчої взаємодії органів державної влади та місцевого самоврядування, що входять в СДСЦЗ.

Виклад основного матеріалу. Питання міжвідомчої взаємодії під час ліквідації наслідків НС в Україні регулюється положеннями декількох нормативно-правових актів, зокрема:

Кодексом ичиільного захисту Украӥни як базовим законодавчим документом у сфері цивільного захисту [12] визначаються повноваження всіх суб'єктів забезпечення цивільного захисту. Так, в частині організації взаємодії, п. 17 ст. 19 «Повноваження Ради міністрів Автономної Республіки Крим, місцевих державних адміністрацій, органів місцевого самоврядування у сфері цивільного захисту» визначає 


\section{Науковий вісник : Державне управління №1 (7) 2021}

організацію їх взаємодії 3 центральним органом виконавчої влади, який забезпечує формування та реалізує державну політику у сфері цивільного захисту, щодо виконання завдань цивільного захисту.

Аналіз повноважень Ради міністрів Автономної Республіки Крим, місцевих державних адміністрацій у сфері цивільного захисту [12] свідчить, що таку взаємодію вони повинні організувати при:

організації аварійно-рятувальних та інших невідкладних робіт, робіт з ліквідації наслідків НС на відповідній території, а також радіаційного, хімічного, біологічного, медичного захисту населення та інженерного захисту територій від наслідків таких ситуацій;

організації та керівництві проведенням відновлювальних робіт з ліквідації наслідків НС;

організації та здійснення евакуації населення, майна у безпечні райони, їх розміщення, створення служб медицини катастроф, необхідних для надання екстреної медичної допомоги та життєзабезпечення населення;

керівництві створеними ними аварійно-рятувальними службами, формуваннями та спеціалізованими службами цивільного захисту, місцевою та добровільною пожежною охороною, забезпечення їх діяльності та здійснення контролю за готовністю до дій за призначенням.

Також, Кодексом цивільного захисту (ст. 73) визначається, що «...для управління у режимі повсякденного функціонування суб'єктами забезпечення цивільного захисту, координації дій органів управління та сил цивільного захисту, здійснення цілодобового чергування та забезпечення функціонування системи збору, оброблення, узагальнення та аналізу інформації про обстановку в районах надзвичайних ситуацій у системі центрального органу виконавчої влади, який забезпечує формування та реалізує державну політику у сфері цивільного захисту, функціонує державний центр управління в НС» [12].

На регіональному рівні у системі центрального органу виконавчої влади, який забезпечує формування та реалізує 
державну політику у сфері цивільного захисту, функціонують центри управління в НС.

У разі виникнення НС відповідні центри управління в НС безпосередньо взаємодіють із штабом з ліквідації наслідків НС у разі його утворення i забезпечують його роботу (ст. 76). Розпорядження і вказівки керівника робіт з ліквідації наслідків НС для персоналу таких центрів управління в НС обов'язкові для виконання.

Залучення сил цивільного захисту до ліквідації наслідків НС здійснюється згідно 3 планами реагування на НС, планами взаємодії органів управління та сил цивільного захисту у разі виникнення НС, а також планами локалізації і ліквідації наслідків аварії (ст. 78).

Положенням про єдину державну систему цивільного захисту [13], що регулює питання здійснення заходів цивільного захисту в державі, визначає склад органів управління та сил цивільного захисту, планування діяльності єдиної державної системи цивільного захисту, порядок виконання нею завдань та організації взаємодії визначено (п. 32), що з метою організації взаємодії між органами управління та силами цивільного захисту функціональних i територіальних підсистем, їх ланок під час ліквідації наслідків конкретних надзвичайних ситуацій зазначеними органами та силами відпрацьовуються плани такої взаємодії.

Також, дане положення має окремий розділ «Взаємодія органів управління та сил цивільного захисту» (п. 47-50).

В СДСЦЗ взаємодія організується 3 питань: визначення органів управління, які безпосередньо залучаються до ліквідації наслідків НС, склад і кількість сил (засобів) реагування на них; погодження порядку здійснення спільних дій сил цивільного захисту під час ліквідації наслідків НС із визначенням основних завдань, місця, часу i способів їх виконання; організації управління спільними діями органів управління та сил цивільного захисту під час виконання завдань за призначенням; всебічного забезпечення спільних заходів, що здійснюватимуться органами управління та підпорядкованими їм силами цивільного 


\section{Науковий вісник : Державне управління №1 (7) 2021}

захисту, в тому числі взаємного надання допомоги транспортними, інженерними, матеріальними, технічними та іншими засобами.

Залежно від обставин, масштабу, характеру та можливого розвитку НС взаємодія організовується: на загальнодержавному рівні - безпосередньо між органами управління та силами функціональних і територіальних підсистем; на регіональному, місцевому та об'єктовому рівні - між територіальними органами центральних органів виконавчої влади, Радою міністрів Автономної Республіки Крим, місцевими органами виконавчої влади, їх силами, а також суб'єктами господарювання.

3 метою запобігання виникненню $\mathrm{HC}$, мінімізації їх можливих наслідків, організації узгодженого реагування сил цивільного захисту на небезпечні події та НС між оперативночерговими (черговими, диспетчерськими) службами органів виконавчої влади всіх рівнів, підприємств, установ та організацій (у разі їх утворення) і оперативно-черговими службами ДСНС організовується обмін інформацією про загрозу або виникнення НС та хід ліквідації іiі наслідків у сфері відповідальності відповідної чергової служби.

Взаємодія під час здійснення заходів щодо запобігання виникненню НС та/або ліквідації їх наслідків організовується через спеціально призначені оперативні групи або представників відповідних центральних та місцевих органів виконавчої влади, Ради міністрів Автономної Республіки Крим, органів місцевого самоврядування, які залучаються до здійснення таких заходів. Повноваження зазначених оперативних груп або представників визначаються відповідними центральними та місцевими органами виконавчої влади, Радою міністрів Автономної Республіки Крим, органами місцевого самоврядування.

Як зазначалось, для організації взаємодії відпрацьовується відповідні плани. На державному рівні Урядом затверджений План реагування на надзвичайні ситуаџії державного рівня, невід'ємною складовою якого є розділ «Взаємодія органів управління і сил цивільного захисту» [14]: 
У цьому розділі визначено, що для своєчасного запобігання виникненню НС і ефективного реагування на них, узгодження спільних дій органів управління, служб i формувань міжвідомчого угруповання сил в єдиній державній системі цивільного захисту організовується взаємодія органів управління і сил цивільного захисту.

Взаємодія органів управління і сил цивільного захисту, що залучаються для запобігання виникненню НС або ліквідації їх наслідків, здійснюється згідно 3 Положенням про єдину державну систему циивільного захисту [13].

Реагування на НC, що пов'язане 3 розповсюдженням коронавірусу, свідчить, що в розпорядчих документах організація взаємодії так і засвідчивулась, не деталізуючи специфіку і iii процедуру [15]. Відповідно до Порядку розроблення планів діяльності ЄДСЦЗ питання щодо організації взаємодії між органами державного управління не передбачено. Це вимагає розробки відповідної інструкції, порядку, що визначав би єдиний протокол організації взаємодії на всіх рівнях управління.

Відповідно до Порядку розроблення планів діяльності єдиної державної системи цивільного захисту [16] ДСНС України, розроблено та направлено керівникам територіальних підсистем ЄДСЦЗ методичні рекомендації з розроблення планів реагування на надзвичайні ситуації регіонального рівня, де питанню взаємодії також присвячено окремий розділ. Однак, як показала практика, питання взаємодії в більшості підсистем СДСЦЗ, як показало дослідження [15], в розпорядчих документах визначалось «встановленим порядком».

Відповідно до Положення про цтаб з ліквідащії наслідків надзвичайної ситуації та Видів оперативно-технічної $i$ звітної документації итабу з ліквідації наслідків надзвичайної ситуациї в частині організації взаємодії, а саме штаб в частині організації взаємодії повинен [18]:

визначити склад i кількість сил цивільного захисту, необхідних для залучення до ліквідації наслідків НС, термінів їх залучення згідно з планами реагування на НC, планами взаємодії органів управління та сил цивільного захисту у разі виникнення 


\section{Науковий вісник : Державне управління №1 (7) 2021}

НC, а також планами локалізації і ліквідації наслідків аварії;

взаємодіяти 3 відповідною спеціальною комісією з ліквідації наслідків НС.

На сьогодні, відповідно до нормативних положень, у разі виникнення НС спеціальна Урядова комісія з ліквідації наслідків $\mathrm{HC}$, яка на період введення режиму НС медико-біологічного характеру не створювалась, повинна взаємодіяти 3 органами управління та силами функціональних i територіальних підсистем через керівника робіт з ліквідації наслідків НС.

Органи управління цивільного захисту відповідно до своїх повноважень взаємодіють на підставі завчасно розроблених планів реагування на НС. В цих планах відповідні органи управління повинні визначити взаємодіючі органи управління i сил цивільного захисту; забезпечити взаємний обмін інформацією про обстановку, що склалася, і подальші дії; визначити порядок всебічного забезпечення спільних заходів та взаємного надання допомоги транспортними, інженерними, матеріальними, технічними та іншими засобами; довести до підлеглих та взаємодіючих органів управління і сил цивільного захисту вимоги щодо порядку оповіщення, управління, зв'язку та обміну інформацією; вжити всіх можливих заходів для підтримання безперервної взаємодії 3 підпорядкованими i взаємодіючими органами управління i силами цивільного захисту, негайно відновлювати взаємодію в разі іiі порушення. У разі змін обстановки і необхідності виконання нових завдань порядок взаємодії уточнюється.

Більш деталізовано питання щодо організації взаємодії визначено у Статуті дій у НС органів управління та підрозділів Оперативно-рятувальної служби цивільного захисту (ОРС ЦЗ) та Статуті дій органів управління та підрозділів ОРС ЦЗ під час гасіння пожеж лише між силами цивільного захисту. У зазначеному Статуті визначено, що взаємодія між органами управління та підрозділами ОРС ЦЗ з іншими силами цивільного захисту, залученими до проведення аварійно-рятувальних та інших невідкладних робіт (АРІНР), організовується відповідно до взаємоузгджених планів та організаційно-розпорядчих 


\section{Науковий вісник : Державне управління №1 (7) 2021}

документів 3 питань взаємодії та визначається в рішенні керівника робіт із НС. Як показує аналіз розпорядчих документів щодо реагування на $\mathrm{HC}$, що пов'язана 3 розповсюдженням COVID19, таке рішення відсутнє, а керівництво ліквідацією взяв на себе Уряд, і свої рішення затверджував відповідними постановами та розпорядженнями. Аналіз цих постанов свідчить, що питання міжвідомчої взаємодії в них було окреслено в узагальненому вигляді.

Може це пов'язано з тим, що з метою організації взаємодії та взаємоінформування в разі загрози або виникнення надзвичайних ситуації ДСНС спільно 3 центральними органами виконавчої влади розроблено відповідну Інструкцію [17] та інші міжвідомчі накази, що затверджені Мін'юстом.

Аналіз зазначеної інструкцією свідчить, що взаємодія здійснюється:

на державному рівні між апаратом ДСНС, апаратом центрального органу управління Національної поліції України та головним органом військового управління Національної гвардії України;

на регіональному рівні між територіальними органами ДСНС, територіальними органами Національної поліції України та органами військового управління оперативно-територіальних об’єднань Національної гвардії України;

на місцевому рівні між підрозділами ДСНС, відділами (відділеннями) в районах, містах, районах у містах Національної поліції України та військовими частинами Національної гвардії України.

Отже, визначена взаємодія лише між вузьким колом органів влади, а спрямування цієї взаємодії більш на взаємоінформування.

Висновки та напрями подальших досліджень. Проблемним питанням державного управління в цілому, та державного управління у сфері цивільного захисту - зокрема, присвячено низку наукових праць однак, незважаючи на вказане, вважаємо, що проблема побудови системи управління ЄДСЦЗ, а також удосконалення послідовності та змісту роботи органів 


\section{Науковий вісник : Державне управління №1 (7) 2021}

управління у надзвичайних ситуаціях та організації взаємодії, як елементу процесу управління, потребує додаткового дослідження та наукового обгрунтування.

Питання організації взаємодії регулюються багатьма нормативними i розпорядчими документами, однак в узагальненому вигляді; процедури, форми, методи організації міжвідомчої взаємодії, окрім взаємоінформування, не визначені за характером та рівнем НС.

Аналіз законодавчих та нормативно-правових актів дозволяє визначити, що:

відповідно до ст. 77 Кодексу изивільного захисту, залучення сил цивільного захисту до ліквідації наслідків НС здійснюється згідно планів реагування на надзвичайні ситуації, планів взаємодії органів управління а також планами локалізації i ліквідації наслідків аварії»;

відповідно до п. 32. Положення про єдину державну систему цивільного захисту, з метою організації взаємодії між органами управління та силами цивільного захисту функціональних i територіальних підсистем, їх ланок під час ліквідації наслідків конкретних НС зазначеними органами та силами відпрацьовуються плани такої взаємодії;

питання організації взаємодії між органами управління та силами цивільного захисту є складовою плану реагування на НC, в якому регулювання міжвідомчої взаємодії винесено в окремий розділ плану.

Як засвідчила практика реагування на $\mathrm{HC}$, проблеми щодо організації взаємодії між органами управління та силами цивільного захисту виникають вже на етапі розробки основного документа із зазначеного питання - плану взаємодії.

Таким чином, нормативно-правове регулювання питання організації взаємодії між органами управління та силами цивільного захисту потребує уточнення та доопрацювання особливо в методах, формах і процедурах організації взаємодії в горизонтальній і вертикальній площині. Це і $\epsilon$ напрямом подальших досліджень. 


\section{Науковий вісник : Державне управління №1 (7) 2021}

\section{Список використаних джерел}

1. Звіт про основні результати діяльності Державної служби України з надзвичайних ситуацій // Офіційний Вебсайт ДСНС України / ДСНС України. URL : https://cutt.ly/tkaSPNt (дата звернення : 29.01.2021).

2. Дослідження методів організації взаємодії між силами цивільного захисту у надзвичайних ситуаціях (шифр - Взаємодія): Звіт про науково-дослідну роботу (остаточний) РК № 0119U000479 / Керівник Потеряйко С. П. К.:ІДУ НД ЦЗ, 2020. 222 с.

3. Бакуменко В. Д. Прийняття рішень в державному управлінні в 2 ч. К. : ВПЦ АМУ, 2010. Ч. 1 : Теоретико-методологічні засади. 276 с.

4. Бакуменко В. Д. Теоретико-методологічні засади формування державно-управлінських рішень : автореф. дис. ... д-ра наук держ. ynp. : cneu. 25.00.01 / Укр. акад. держ. упр. при Президентові України. Київ, 2001. 35 с.

5. База науково-дослідних та дослідно-конструкторських робіт / Уклад. Борисов А. В. // Офіційний Вебсайт ДСНС України / ДСНС України. URL : http://ndr.dsns.gov.ua/ (дата звернення 29.01.2020).

6. Волянський П. Б., Свсюков О. П., Терент'єва А. В. Кризовий менеджмент як наукова складова управлінських рішень у сфері цивільного захисту. Науковий збірник Інституту державного управління у сфері иивільного захисту. №7. 2019. С. 36 - 49. URL : https://doi.org/10.35577/iducz.2019.07.04 (дата звернення 29.02.2021).

7. Костенко В. О. Діяльність місцевої влади у сфері цивільного захисту i надзвичайних ситуацій в контексті реформи місцевого самоврядування в Україні. Теорія та практика державного управління. Харків, 2014. Вип. 2 (45). С. $158-165$.

8. Волянський П. Б. Принципи взаємодії сил цивільного захисту в міжнародних гуманітарних операціях з ліквідації медико-санітарних наслідків надзвичайних ситуацій. Державне управління: удосконалення та розвиток : електрон. наук. фахове вид. 2013. № 3. URL: http://nbuv.gov.ua/UJRN/Duur_2013_3_16 (дата звернення: 23.12.2020).

9. Михайлов В. М. Взаємодія органів місцевого самоврядування 3 органами державної влади у сфері запобігання та ліквідації надзвичайних ситуацій: автореф. дис. ... к.держ.упр. : 25.00.04 / Націон. акад. держ. упр. при Президентові України. Київ, 2013. 22 с.

10. Бєлікова К., Кравченко Ю., Потеряйко С., Марченко О. Організація взаємодії між органами управління у надзвичайних ситуаціях: правовий, організаційний та економічний аспекти. Науковий вісник : 


\section{Науковий вісник : Державне управління №1 (7) 2021}

Державне управління. №4(6).2020. С. 6-29. URL : https://doi.org/10.32689/2618-0065-2020-4(6)-6-29 (дата звернення : 29.01.2020).

11. Гур'єв С. О., Іскра Н. І., Терент'єва А. В. Інформаційна взаємодія в умовах надзвичайних ситуацій медико-біологічного характеру. Науковий вісник: держсавне управління. 2020. № 4 (6). С. 68 - 92.

12. Кодекс цивільного захисту України: Закон України від 2.10.2012 5403-VI // База даних “Законодавство України” / ВР України. https://zakon.rada.gov.ua/laws/show/5403-17\#Text : (дата звернення: 20.12.2020).

13. Про затвердження Положення про єдину державну систему цивільного захисту : постанова Кабінету Міністрів України від 09.01.2014 № 11 // База даних “Законодавство України” / ВР України. URL : https://zakon.rada.gov.ua/laws/show/11-2014$\% \mathrm{D} 0 \% \mathrm{BF} \# \mathrm{Text}$ (дата звернення 20.12.2020).

14. Про затвердження Плану реагування на надзвичайні ситуації державного рівня : постанова Кабінету Міністрів України від 14.03.2018 № 223 // База даних “Законодавство України” / ВР України. URL : https://zakon.rada.gov.ua/laws/show/223-2018$\% \mathrm{D} 0 \% \mathrm{BF} \# \mathrm{Text}$ (дата звернення 20.12.2020).

15. Литвиновський $€$. Ю. Деякі результати спостереження за організацією функціонування територіальної підсистеми єдиної державної системи цивільного захисту. Науковий вісник : державне управління. №4(6). 2020. C. 160-185. URL : https://doi.org/10.32689/2618-0065-2020-4(6)-160-185 (дата звернення 30.12.2020).

16. Про затвердження Порядку розроблення планів діяльності єдиної державної системи цивільного захисту : постанова Кабінету Міністрів України від 09.08.2017 № 626 // База даних “Законодавство України” / BP України. URL : https://zakon.rada.gov.ua/laws/show/626-2017-\%D0\%BF\#Text (дата звернення : 20.12.2020).

17. Про затвердження Інструкції про порядок взаємодії між Державною службою України з надзвичайних ситуацій, Національною поліцією України та Національною гвардією України у сфері запобігання і реагування на надзвичайні ситуації, пожежі та небезпечні події : Наказ МВС України від 22.08.2016 № 859 // База даних “Законодавство України” / BP України. URL : https://zakon.rada.gov.ua/laws/show/z1254-16\#Text (дата звернення : 20.12.2020). 


\section{Науковий вісник : Державне управління №1 (7) 2021}

18. Про затвердження Положення про штаб 3 ліквідації наслідків надзвичайної ситуації та Видів оперативно-технічної і звітної документації штабу з ліквідації наслідків надзвичайної ситуації : наказ МВС України від 26.12.2014 № 1406 // База даних “Законодавство України” / BP України. URL : https://zakon.rada.gov.ua/laws/show/z0047-15\#Text (дата звернення : 20.12.2020).

\section{References}

1. Zvit pro osnovni rezultaty diialnosti Derzhavnoi sluzhby Ukrainy $\mathrm{z}$ nadzvychainykh sytuatsii [Report on the main results of the State Service of Ukraine for Emergencies] // Ofitsiinyi Vebsait DSNS Ukrainy / DSNS Ukrainy. URL : https://cutt.ly/tkaSPNt (access date: 29.01.2021) [in Ukrainian].

2. Doslidzhennia metodiv orhanizatsii vzaiemodii mizh sylamy tsyvilnoho zakhystu u nadzvychainykh sytuatsiiakh (shyfr - Vzaiemodiia) [Research of methods of organization of interaction between civil defense forces in emergency situations (code - Interaction)] : Zvit pro naukovo-doslidnu robotu (ostatochnyi). PK № 0119U000479 / Kerivnyk Poteriaiko S.P. K.:IDU ND TsZ, 2020. 222 s. [in Ukrainian].

3. Bakumenko, V. D. (2010). Pryiniattia rishen v derzhavnomu upravlinni. [Decision making in public administration]. (Vols. 1). Kyiv: VPTs AMU [in Ukrainian].

4. Bakumenko, V.D. (2001). Teoretyko-metodolohichni zasady formuvannya derzhavno-upravlinskykh rishen [Theoretical and methodological principles of formation of public administration decisions]. Extended abstract of doctor's thesis. Kyiv: UAPA [in Ukrainian].

5. Baza naukovo-doslidnykh ta doslidno-konstruktorskykh robit [Base of research and development works] Uklad. Borysov A. V. // Ofitsiinyi Vebsait DSNS Ukrainy / DSNS Ukrainy. URL : http://ndr.dsns.gov.ua/ (data zvernennia 29.01.2020) [in Ukrainian].

6. Volianskyi P. B., Yevsiukov O. P., Terentieva A. V. Kryzovyi menedzhment yak naukova skladova upravlinskykh rishen $\mathrm{u}$ sferi tsyvilnoho zakhystu [Crisis management as a scientific component of management decisions in the field of civil protection]. Naukovyi zbirnyk Instytutu derzhavnoho upravlinnia u sferi tsyvilnoho zakhystu. №7. 2019. S. 36-49. URL : https://doi.org/10.35577/iducz.2019.07.04 (data zvernennia 29.02.2021) [in Ukrainian].

7. Kostenko, V. O. (2014). Diyalnist mistsevoyi vlady u sferi tsyvilnoho zakhystu i nadzvychaynykh sytuatsiy $\mathrm{v}$ konteksti reformy mistsevoho samovryaduvannya $\mathrm{v}$ Ukrayini [Activities of local authorities in the 


\section{Науковий вісник : Державне управління №1 (7) 2021}

sphere of civil protection and emergencies in the context of local government reform in Ukraine. Theory and practice of public administration]. Teoriya ta praktyka derzhavnoho upravlinnya - Theory and practice of public administration, 2 (45), 158 - 165[in Ukrainian].

8. Volianskyi, P. B. (2013). Pryntsypy vzaiemodii syl tsyvilnoho zakhystu v mizhnarodnykh humanitarnykh operatsiiakh $\mathrm{z}$ likvidatsii medykosanitarnykh naslidkiv nadzvychainykh sytuatsii. [Principles of interaction of civil defense forces in international humanitarian operations to eliminate the health consequences of emergencies]. Derzhavne upravlinnia: udoskonalennia ta rozvytok - Public administration: improvement and development, 3. URL http://www.dy.nayka.com.ua/?op=1\&z=588. [in Ukrainian].

9. Mykhaylov, V. M. (2013). Vzayemodiya orhaniv mistsevoho samovryaduvannya $\mathrm{z}$ orhanamy derzhavnoyi vlady u sferi zapobihannya ta likvidatsiyi nadzvychaynykh sytuatsiy [Interaction of local selfgovernment bodies with state authorities in the field of prevention and liquidation of emergencies]. Extended abstract of candidate's thesis. Kyiv: NAPA [in Ukrainian].

10. Bielikova K., Kravchenko Yu., Poteriaiko S., Marchenko O. Orhanizatsiia vzaiemodii mizh orhanamy upravlinnia u nadzvychainykh sytuatsiiakh: pravovyi, orhanizatsiinyi ta ekonomichnyi aspekty [Organization of interaction between management bodies in emergency situations: legal, organizational and economic aspects]. Naukovyi visnyk : Derzhavne upravlinnia. №4(6).2020. S. 6 - 29. URL : https://doi.org/10.32689/2618-0065-2020-4(6)-6-29 (data zvernennia : 29.01.2020) [in Ukrainian].

11. Huriev, S. O., Iskra, N. I. \& Terentieva, A. V. (2020). Informatsiyna vzayemodiya $\mathrm{V}$ umovakh nadzvychaynykh sytuatsiy medykobiolohichnoho kharakteru [Information interaction in emergencies of medical and biological nature]. Naukovyy visnyk: derzhavne upravlinnya - Scientific Bulletin: Public Administration, 4(6), 68 - 92 [in Ukrainian].

12. Zakon Ukrainy "Kodeks tsyvilnoho zakhystu Ukrainy" vid 02.10.2012 № 5403-VI. [Law of Ukraine "Code of Civil Protection of Ukraine" from October 2, 2012 № 5403-VI] (n.d.) zakon.rada.gov.ua URL : https://zakon.rada.gov.ua/laws/show/5403-17\#Text [in Ukrainian].

13. Postanova Kabinetu Ministriv Ukrainy "Pro zatverdzhennia Polozhennia pro yedynu derzhavnu systemu tsyvilnoho zakhystu" vid 09.01.2014 № 11. [Decree of the Cabinet of Ministers of Ukraine "On approval of the Regulation on the unified state system of civil protection" from January 9, 2014 № 11] (n.d.) zakon.rada.gov.ua URL : https://zakon.rada.gov.ua/laws/show/11-2014-\%D0\%BF\#Text [in Ukrainian].

14. Postanova Kabinetu Ministriv Ukrayiny "Pro zatverdzhennya Planu reahuvannya na nadzvychayni sytuatsiyi derzhavnoho rivnya" vid 
14.03.2018 № 223. [Resolution of the Cabinet of Ministers of Ukraine "On approval of the State Emergency Response Plan" from March 14, 2018 № 223] (n.d.) zakon.rada.gov.ua URL : https://zakon.rada.gov.ua/laws/show/223-2018-\%D0\%BF\#Text

15. Lytvynovskyi Ye. Yu. Deiaki rezultaty sposterezhennia za orhanizatsiieiu funktsionuvannia terytorialnoi pidsystemy yedynoi derzhavnoi systemy tsyvilnoho zakhystu. [Some results of observation of the organization of functioning of the territorial subsystem of the unified state system of civil defense]. Naukovyi visnyk : derzhavne upravlinnia. №4(6). 2020. S. 160-185. URL : https://doi.org/10.32689/2618-00652020-4(6)-160-185 (data zvernennia 30.12.2020).

16. Postanova Kabinetu Ministriv Ukrayiny "Pro zatverdzhennya Poryadku rozroblennya planiv diyal'nosti yedynoyi derzhavnoyi systemy tsyvilnoho zakhystu" vid 09.08.2017 № 626 [Cabinet of Ministers of Ukraine "On approval of the development plans of the unified state civil defense system” from August 09, 2017 № 626] (n.d.) zakon.rada.gov.ua URL : https://zakon.rada.gov.ua/laws/show/626-2017-\%D0\%BF\#Text [in Ukrainian].

17. Nakaz MVS Ukrayiny "Pro zatverdzhennya Instruktsiyi pro poryadok vzayemodiyi mizh Derzhavnoyu sluzhboyu Ukrayiny z nadzvychaynykh sytuatsiy, Natsionalnoyu politsiyeyu Ukrayiny ta Natsionalnoyu hvardiyeyu Ukrayiny $u$ sferi zapobihannya i reahuvannya na nadzvychayni sytuatsiyi, pozhezhi ta nebezpechni podiyi" vid 22.08.2016 № 859 [Order of MIA of Ukraine "On Approval of Instruction on the interaction between the State Emergency Service of Ukraine, the National Police and the National Guard Ukraine Ukraine in preventing and responding to emergencies, fires and hazardous events" from August 22, 2016 № 859] (n.d.) zakon.rada.gov.ua URL : https://zakon.rada.gov.ua/laws/show/z1254-16\#Text [in Ukrainian].

18. Nakaz MVS Ukrayiny "Pro zatverdzhennya Polozhennya pro shtab z likvidatsiyi naslidkiv nadzvychaynoyi sytuatsiyi ta Vydiv operatyvnotekhnichnoyi i zvitnoyi dokumentatsiyi shtabu z likvidatsiyi naslidkiv nadzvychaynoyi sytuatsiyi” vid 26.12.2014 № 1406 [Order of the Ministry of Internal Affairs of Ukraine "On approval of the Regulations on the emergency response headquarters and Types of operational and technical and reporting documentation of the emergency response headquarters" from December 26, 2014 № 1406 ”] (n.d.) zakon.rada.gov.ua URL : https://zakon.rada.gov.ua/laws/show/z004715\#Text [in Ukrainian]. 


\title{
STATE OF REGULATORY REGULATION OF INTERDEPARTMENTAL INTERACTION OF STATE AUTHORITIES AND LOCAL SELF-GOVERNMENT
}

\section{Demchuk Volodymyr}

\begin{abstract}
Analysis of hazards and threats of man-made and natural nature, emergencies shows that over the past 10 years there is no tendency to increase or decrease, but it should be noted that the level of risks of natural and man-made emergencies and risks of losses from them remain virtually unchanged and quite high for most regions of Ukraine. And the consequences of the emergency associated with the spread of the coronavirus COVID-19 are unpredictable and require scientific and methodological justification of methods for their prediction and calculation. As the situation in the world with the spread of coronavirus has shown, the risk of emergencies is a factor that determines the quality of life in the regions of any country. This necessitates a detailed review of organizational and managerial approaches to their modeling and minimization. Traditional approaches to managing the complex consequences of emergencies, as evidenced by the experience of their application, often lead to unsatisfactory results. Another serious problem in the organization of effective emergency management, as shown by the practice of responding to emergencies associated with the spread of the coronavirus, is the real complication or lack of coordination of official governmental, departmental and nongovernmental authorities. It is revealed that the legislation of Ukraine defines the main provisions for the implementation of state policy in the sphere of civil protection in general, and outlines the foundations for building a single state system of civil protection. It is proved that the specified legislative acts indicate the structure, functions and tasks of the management system of the unified state system of civil protection. It is determined that the problem of building the management system of the unified state civil protection system at the territorial and functional level, as well as improving the sequence and content of management in emergencies and the organization of interaction, as part of the management process, requires additional research and scientific substantiation.
\end{abstract}

Key words: normative-legal regulation, interdepartmental interaction, civil protection, emergency situation, COVID-19. 